Abstracta Iranica Abstracta Iranica

Revue bibliographique pour le domaine irano-aryen

Volume 26 | 2005

Comptes rendus des publications de 2003

\title{
"Women in Afghanistan: passive victims of the borga or active social participants? ». Development in Practice, 13, 2 - 3, (mai 2003), pp. 266-277.
}

\section{Azadeh Kian-Thiébaut}

\section{OpenEdition}

1 Journals

\section{Édition électronique}

URL : http://journals.openedition.org/abstractairanica/1750

ISSN : 1961-960X

Éditeur:

CNRS (UMR 7528 Mondes iraniens et indiens), Éditions de l'IFRI

Édition imprimée

Date de publication : 15 mai 2005

ISSN : 0240-8910

\section{Référence électronique}

Azadeh Kian-Thiébaut, « « Women in Afghanistan: passive victims of the borga or active social participants? ». Development in Practice, 13, 2 - 3, (mai 2003), pp. 266-277. », Abstracta Iranica [En ligne], Volume 26 | 2005, document 427, mis en ligne le 07 décembre 2005, consulté le 25 septembre 2020. URL : http://journals.openedition.org/abstractairanica/1750

Ce document a été généré automatiquement le 25 septembre 2020.

Tous droits réservés 
« Women in Afghanistan: passive victims of the borga or active social participants? ». Development in Practice, 13, 2 - 3, (mai 2003), pp. 266-277.

\author{
Azadeh Kian-Thiébaut
}

1 Se fondant sur son travail de terrain à Kabul en février 2002, l'A. analyse la diversité des expériences des femmes et des hommes dans la guerre et refuse d'adhérer à la vision dominante qui présente les femmes afghanes comme les victimes passives de la guerre. A travers l'analyse des stratégies de survie de diverses catégories de femmes, qu'elles soient instruites et actives ou pauvres et analphabètes, E. Rostami Pavey les présentent comme actrices sociales et démontre que les Afghanes se sont organisées entre femmes, ont travaillé ensemble dans les groupes et organisations, fondé des réseaux et créé des normes. Ces femmes, parmi lesquelles se trouvent beaucoup de chefs de ménage du fait $\mathrm{du}$ décès de leurs époux pendant la guerre civile, condamnent tant les Mudjahedins pour avoir violé et massacré les femmes afghanes que les Talibans qui les ont privé d'éducation et de travail poussant ainsi les plus pauvres d'entre elles à la prostitution et aux mariages forcés avec les talibans, ces étudiants en théologie. Si la reconstruction économique constitue la demande la plus urgente des femmes afghanes, elles revendiquent aussi la participation plus active des femmes à la reconstruction de leur pays et leur présence dans les sphères du pouvoir. 
INDEX

Keywords : Afghanistan, Women

Mots-clés : femmes

Thèmes : 12.2. Afghanistan

nompropre Kabul

\section{AUTEURS}

\section{AZADEH KIAN-THIÉBAUT}

CNRS - Paris 